Prepared in cooperation with the Texas Water Development Board

\title{
Trend Analysis and Selected Summary Statistics of Annual Mean Streamflow for 38 Selected Long-Term U.S. Geological Survey Streamgages in Texas, Water Years 1916-2012
}

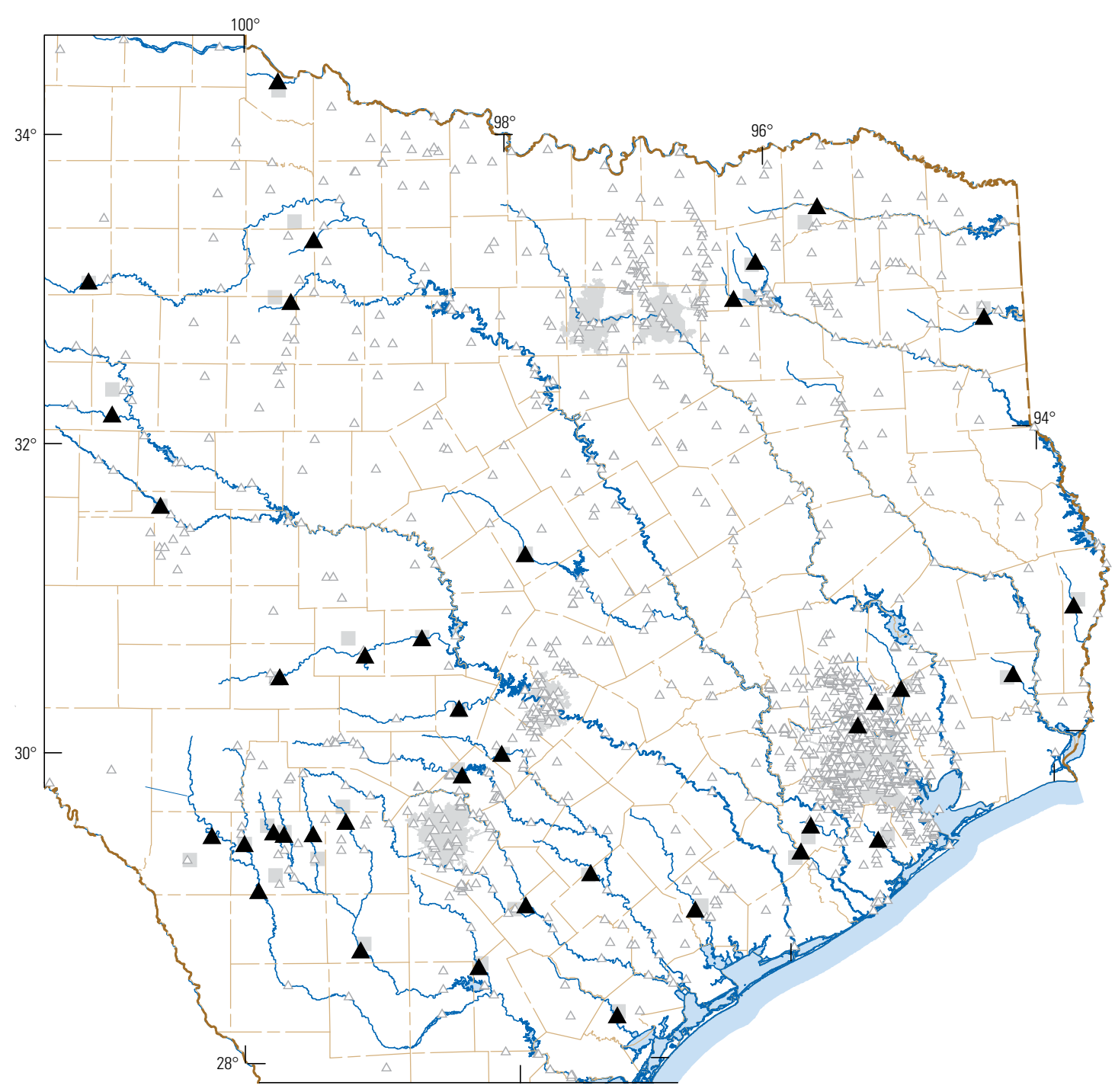

Scientific Investigations Report 2013-5230

Version 1.1, August 2014 



\section{Trend Analysis and Selected Summary Statistics of Annual Mean Streamflow for 38 Selected Long-Term U.S. Geological Survey Streamgages in Texas, Water Years 1916-2012}

By William H. Asquith and Dana L. Barbie

Prepared in cooperation with the Texas Water Development Board

Scientific Investigations Report 2013-5230

Version 1.1, August 2014 


\title{
U.S. Department of the Interior \\ SALLY JEWELL, Secretary
}

\section{U.S. Geological Survey \\ Suzette M. Kimball, Acting Director}

\author{
U.S. Geological Survey, Reston, Virginia: \\ First release: 2014 \\ Revised: August 2014 (ver. 1.1)
}

\begin{abstract}
For more information on the USGS - the Federal source for science about the Earth, its natural and living resources, natural hazards, and the environment, visit http://www.usgs.gov or call 1-888-ASK-USGS.

For an overview of USGS information products, including maps, imagery, and publications, visit http://www.usgs.gov/pubprod

To order this and other USGS information products, visit http://store.usgs.gov
\end{abstract}

Any use of trade, firm, or product names is for descriptive purposes only and does not imply endorsement by the U.S. Government.

Although this information product, for the most part, is in the public domain, it also may contain copyrighted materials as noted in the text. Permission to reproduce copyrighted items must be secured from the copyright owner.

Suggested citation:

Asquith, W.H., and Barbie, D.L., 2014, Trend analysis and selected summary statistics of annual mean streamflow for 38 selected long-term U.S. Geological Survey streamgages in Texas, water years 1916-2012 (ver. 1.1, August 2014): U.S. Geological Survey Scientific Investigations Report 2013-5230, 16 p., http://dx.doi.org/10.3133/sir20135230.

ISSN 2328-031X (print)
ISSN 2328-0328 (online)

ISSN 2328-0328 (online)

ISBN 978-1-4113-3760-2 


\section{Contents}

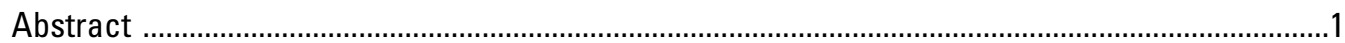

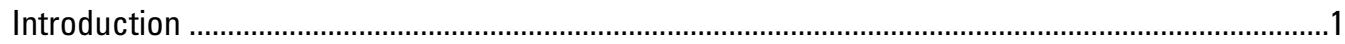

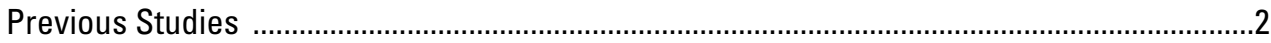

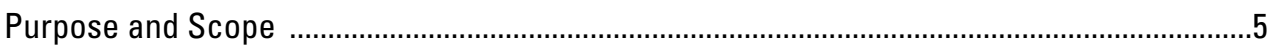

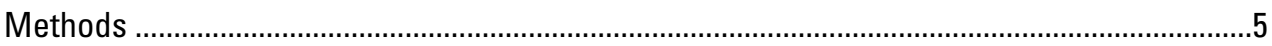

Trend Analysis and Selected Summary Statistics of Annual Mean Streamflow ..............................

Trend Analysis of Annual Mean Streamflow ........................................................................

Selected Summary Statistics of Annual Mean Streamflow ......................................................

An Example Application of Regional Analysis of Annual Mean Streamflow Frequency .........9

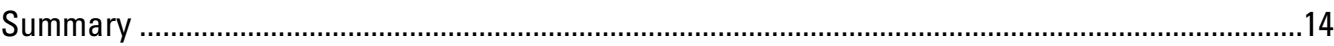

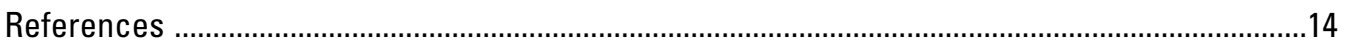

\section{Figures}

1. Map showing locations of 38 selected long-term U.S. Geological Survey streamgages in Texas providing streamflow data anticipated to represent natural and unregulated watershed conditions

2. Graph showing comparison of periods of operation for 38 selected long-term U.S. Geological Survey streamgages in Texas by sequence number listed in table 1 and identification of three stations with a statistically significant trend in annual mean streamflow by the nonparametric Kendall's tau statistical test

3. Graph showing comparison of three annual mean frequency curves in probability-density (inset) and quantile-function (main plot) form for U.S. Geological Survey streamgage 08123800 Beals Creek near Westbrook, Texas (table 1), associated with example application

\section{Tables}

1. Summary of data from 38 selected long-term U.S. Geological Survey streamgages in Texas providing streamflow data anticipated to represent natural and unregulated watershed conditions

2. Summary of mean annual streamflow, Kendall's tau and associated p-value (probability value), and declaration of statistical significance with respect to trend direction for the selected long-term U.S. Geological Survey streamgages in Texas

3. Summary of first six L-moments of base-10 logarithms of offset annual mean streamflow and sampling variances computed by bootstrap simulation of 10,000 replications for the selected long-term U.S. Geological Survey streamgages in Texas 


\section{Conversion Factors}

Inch/Pound to SI

\begin{tabular}{lcl}
\hline \multicolumn{1}{c}{ Multiply } & By & \multicolumn{1}{c}{ To obtain } \\
\hline foot $(\mathrm{ft})$ & Length & meter $(\mathrm{m})$ \\
mile $(\mathrm{mi})$ & 0.3048 & kilometer $(\mathrm{km})$ \\
\hline & 1.609 & \\
\hline square mile $\left(\mathrm{mi}^{2}\right)$ & Area & square kilometer $\left(\mathrm{km}^{2}\right)$ \\
\hline & 2.590 & \\
\hline cubic foot $\left(\mathrm{ft}^{3}\right)$ & Volume & cubic meter $\left(\mathrm{m}^{3}\right)$ \\
acre-foot $(\mathrm{acre}-\mathrm{ft})$ & 0.02832 & cubic meter $\left(\mathrm{m}^{3}\right)$ \\
\hline & 1,233 & \\
\hline foot per second $(\mathrm{ft} / \mathrm{s})$ & Flow rate & meter per second $(\mathrm{m} / \mathrm{s})$ \\
cubic foot per second $\left(\mathrm{ft}^{3} / \mathrm{s}\right)$ & 0.3048 & cubic meter $\mathrm{per}$ second $\left(\mathrm{m}^{3} / \mathrm{s}\right)$ \\
\hline
\end{tabular}

Vertical coordinate information is referenced to the North American Vertical Datum of 1988 (NAVD 88).

Horizontal coordinate information is referenced to the North American Datum of 1983 (NAD 83).

A water year is the 12-month period October 1 through September 30 designated by the calendar year in which it ends. 


\title{
Trend Analysis and Selected Summary Statistics of Annual Mean Streamflow for 38 Selected Long-Term U.S. Geological Survey Streamgages in Texas, Water Years 1916-2012
}

\author{
By William H. Asquith and Dana L. Barbie
}

\section{Abstract}

In 2013, the U.S. Geological Survey (USGS) operated more than 500 continuous streamgages (streamflow-gaging stations) in Texas. In cooperation with the Texas Water Development Board, the USGS evaluated mean annual streamflow data for 38 selected streamgages that were active as of water year 2012. The 38 streamgages have annual mean streamflow data considered natural and unregulated. Collected annual mean streamflow data for a single streamgage ranged from 49 to 97 cumulative years. The nonparametric Kendall's tau statistical test was used to detect monotonic trends in annual mean streamflow over time. The monotonic trend analysis detected 2 statistically significant upward trends ( 0.01 one-tail significance), 1 statistically significant downward trend ( 0.01 one-tail significance level), and 35 instances of no statistically significant trend $(0.02$ two-tailed significance level). The Theil slope estimate of a regression slope of annual mean streamflow with time was computed for the three stations where trends in streamflow were detected: 2 increasing Theil slopes were measured $(+0.40$ and +2.72 cubic feet per second per year, respectively), and 1 decreasing Theil slope $(-0.24$ cubic feet per second per year) was measured.

Selected summary statistics (L-moments) and estimates of respective sampling variances were computed for the 35 streamgages lacking statistically significant trends. From the L-moments and estimated sampling variances, weighted means or regional values were computed for each L-moment. An example application is included demonstrating how the L-moments could be used to evaluate the magnitude and frequency of annual mean streamflow.

\section{Introduction}

Streamflow resources are inherently vital to the ecological and economic viability of Texas. In 2013, the U.S. Geological Survey (USGS) operated more than 500 continuous streamgages (streamflow-gaging stations) in
Texas; the data and ancillary information are stored in the USGS National Water Information System (NWIS) database (U.S. Geological Survey, 2013). Long-term streamflow data, which are anticipated to be representative of natural and unregulated watershed conditions, are useful for evaluation of changes (trends) in streamflow attributable to systematic landuse changes, changes in groundwater gains or losses, climate cycles and changes, statistical vagaries, and other influencing factors. Long-term data are defined for this investigation as having at least 49 years of cumulative record. Magnitude and frequency analysis of extreme streamflow conditions and events (rare high-, low-, and drought-condition streamflows) is improved (uncertainty reduced) with statistics of large sample sizes provided by long-term streamflow datasets. The terms "natural and unregulated" do not indicate that the annual mean streamflow data are not to a minor degree affected by land-use changes, municipality development, flood-control regulation, or other water resources development infrastructure. Often there are diversions upstream for ranch or farm use, and municipalities exist within each of the watersheds.

Additionally, streamgages flagged as "regulated" as of 2013 in the annual peak streamflow database within NWIS (http://nwis.waterdata.usgs.gov/tx/nwis/peak) were not included in the analyses. As described by Asquith (2001), two commonly used classification schemes consider regulated stations or individual peak streamflows as (1) those stations where at least 10 percent of the contributing drainage area of the basin is affected or controlled by reservoirs, or (2) those peak annual streamflows affected to an appreciable degree. The later scheme has an aspect of hydrologic judgment. USGS hydrologists assign a numeric code of " 6 " in the annual peak streamflow database to a streamgage to designate peak streamflows affected by regulation. As a matter of general logic and database consistency, once the annual peaks at a station are classified with a code " 6 " that code remains in place for all subsequent annual peaks. Although used for this investigation in part for streamgage eligibility, it is important to note that the numeric code of " 6 " is primarily associated with classification of annual instantaneous peak streamflows in contrast to annual mean streamflow. 
About two-thirds of the total freshwater usage in Texas consists of surface water (Kenny and others, 2009, p. 6). There are approximately 200 reservoirs with a substantial flood-storage capacity of 3,000 acre-feet (acre-ft) or more throughout Texas (Dowell, 1964; Asquith, 2001; Texas State Historical Association, 2013). Total storage capacity at these reservoirs is approximately 25 million acre-ft. There are many permitted and nonpermitted diversion- and return-flow points throughout watersheds and river basins in Texas (Texas Commission on Environmental Quality, 2013), a fact that complicates the task of identifying natural and unregulated annual peak streamflows unaffected by substantial reservoiror other water-development activities in Texas (Asquith, 2001). Although hundreds of streamgages were active in Texas in 2013 (fig. 1), many were located in watersheds with obvious upstream regulation by large-scale flood-control infrastructure, large metropolitan areas, or other urbanized land uses.

Streamflow statistics for unregulated streams in Texas are useful in resource assessments (such as water-supply studies) and to water managers, hydrologists, biologists, and ecologists for various types of hydrologic studies. For example, longterm streamflow data that are representative of natural and unregulated watershed conditions are useful for evaluation of changes (upward or downward trends) in streamflow attributable to systematic land-use changes, changes in groundwater gains or losses, assessments of climate cycles, and investigations of climate-related changes in streamflow. Annual mean streamflow data for unregulated watersheds can be used to compute mean annual streamflow over long periods of time and represent the expected annual volume of water measured at a streamgage. Magnitude and frequency analyses of extreme streamflow conditions and events (rare high-, low-, and drought-condition streamflows) are enhanced (uncertainty reduced) with statistics of large sample sizes provided by long-term datasets of natural unregulated streamflow.

Accordingly, the USGS, in cooperation with the Texas Water Development Board, evaluated annual mean streamflow data for 38 selected, long-term USGS streamgages that were active as of water year 2012 and considered natural and unregulated (fig. 1, table 1). Individually, the 38 streamgages have at least 49 and as many as 97 years of annual mean streamflow data; the average period of record is 68 years. The minimum contributing drainage area (CDA) is about 43 square miles $\left(\mathrm{mi}^{2}\right)$, the mean CDA is about $788 \mathrm{mi}^{2}$, and the maximum CDA is about $4,190 \mathrm{mi}^{2}$. Streamgages throughout the entire State were considered; the streamgages are located throughout the central and eastern parts of Texas as shown in figure 1.

\section{Previous Studies}

Retrospective studies of Texas streamflow data encompass a considerable body of work from which subsequent investigations have been and can be based. Statistical and historical summaries of streamflow data in
Texas within the past 15 years have been published, including Lanning-Rush (2000), Asquith (2001), Asquith and others (2007a, b), Asquith and Heitmuller (2008), Asquith and Roussel (2009), Barbie and Wehmeyer (2012), Barbie and others (2012), and Winters (2013). Each of these studies considers a broader spectrum of streamflow characteristics (statistics) and stations (specific study areas) than does this investigation. The previous studies provide considerable graphical depictions of streamflow history and augment time series graphics and tables that are readily obtained by public users of the USGS NWIS interface known as NWISWeb (http://waterdata.usgs.gov).

Lanning-Rush (2000) provided regional regression equations to estimate mean annual streamflow (arithmetic mean of the annual mean streamflows) as well as mean seasonal (spring, summer, fall, winter) streamflow for unmonitored stream sites throughout Texas. The regression equations by Lanning-Rush (2000) are based on the statistical relation between mean annual streamflow (as well as seasonal streamflow), contributing drainage area, and mean annual (or seasonal) precipitation. Lanning-Rush (2000) evaluated mean streamflow values in Texas.

Asquith and Roussel (2009) provided regional regression equations for estimation of annual peak streamflow quantiles, such as the 0.5 or 0.9 annual nonexceedance probabilities, which can be interpreted as cumulative percentiles, of the annual peak streamflows (for example, the 0.9 probability peak streamflow would be representative of substantial storm flow that has on average a 1 in 10 chance of being equaled or exceeded in any 1 year). Asquith and Roussel (2009) provided a thematic template for regionalization of other streamflow characteristics in Texas; as of 2013, a similar study of annual mean streamflow quantiles in Texas has not been published.

Retrospective studies similar to the 2013 investigation include Barbie and Wehmeyer (2012), which evaluated trends in selected streamflow statistics for 19 long-term streamgages assumed to represent outflows from Texas, and Barbie and others (2012), which evaluated trends in selected streamflow statistics for one west Texas river basin. Asquith (2001) did a statewide study of the effects of flood-control regulations on statistics of annual peak streamflow for more than 300 hundred streamgages in Texas. As a part of the Asquith and Roussel (2009) study, periods of natural and unregulated annual peak streamflow records were identified. Data files by station from Asquith and Roussel (2009) were consulted as a component of screening of streamgages for inclusion in this investigation.

Winters (2013) provided historical perspective of the 2011 drought in Texas to the drought of 1951-56 for 19 selected unregulated streamgages in Texas. Fifteen of those 19 streamgages are also part of this investigation (table 1). Table 1 lists those streamgages in common with Winters (2013), streamgages not included in Winters (2013) because the streamflow is not generally considered perennial, and those not eligible for inclusion in Winters (2013) because of the start of data record. 


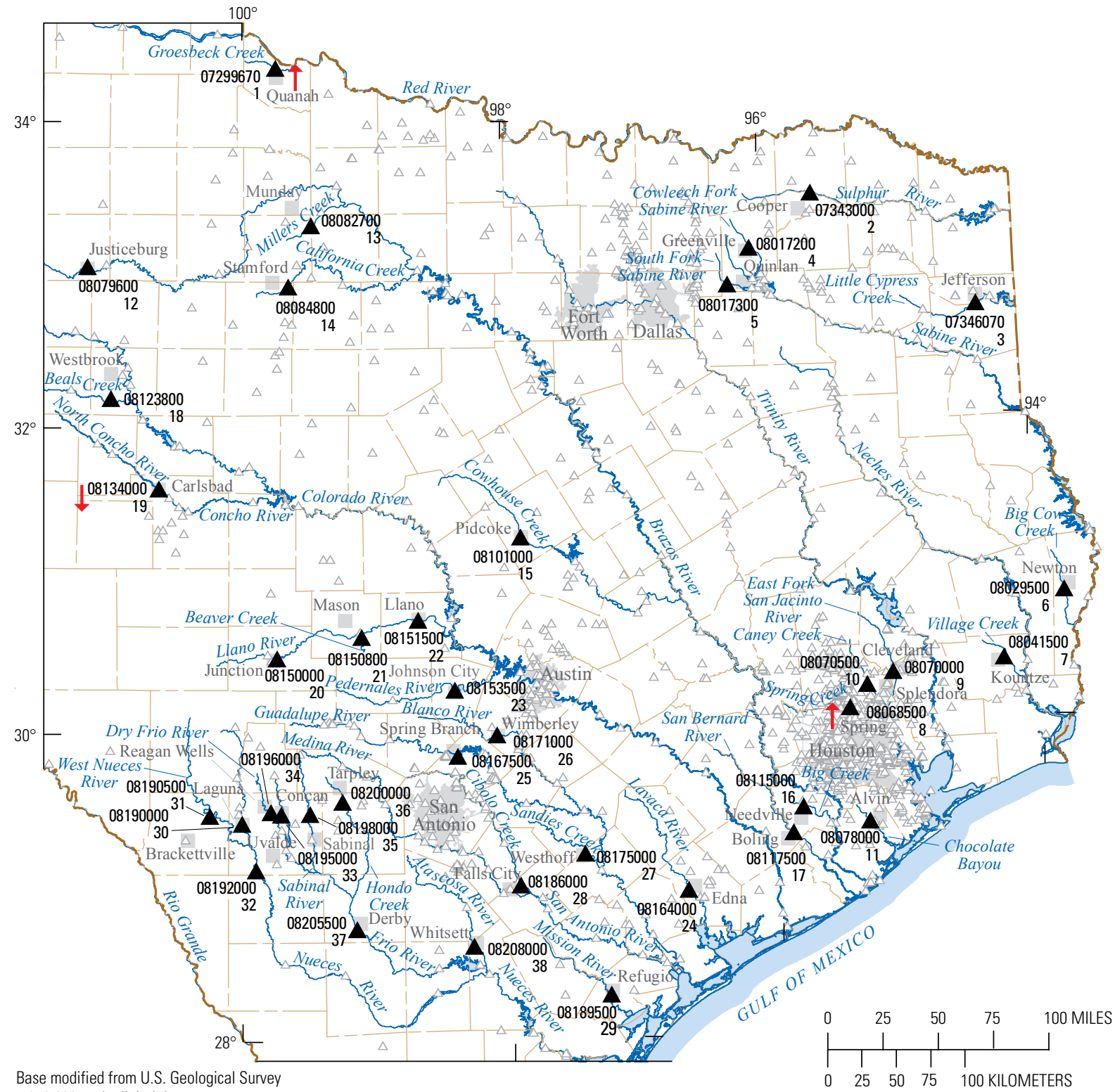

Base modified from U.S. Geological Survey

1:250,000 scale digital data

Texas Centric Mapping System

Lambert Conformal Conic projection

North American Datum of 1983

EXPLANATION

$08070000 \Delta$ U.S. Geological Survey streamgage, station number

9 and map identifier with long-term unregulated record-Table 1

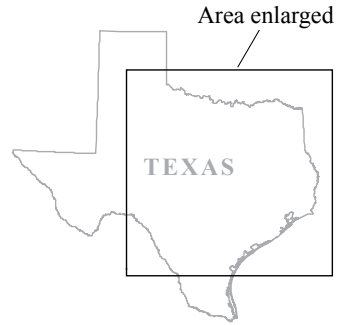

U.S. Geological Survey streamgage currently (2013) active in Texas and within the inset area that did not meet the long-term unregulated criteria

$\uparrow$ Upward trend by the nonparametric Kendall's tau statistical test-Table 2

$\downarrow$ Downward trend by the nonparametric Kendall's tau statistical test-Table 2

Figure 1. Locations of 38 selected long-term U.S. Geological Survey streamgages in Texas providing streamflow data anticipated to represent natural and unregulated watershed conditions. 
Table 1. Summary of data from 38 selected long-term U.S. Geological Survey streamgages in Texas providing streamflow data anticipated to represent natural and unregulated watershed conditions.

[mi², square miles; --, not eligible, no record back to 1951-56; ${ }^{\circ}$, degrees; ', minutes; ", seconds; SH, State Highway; DMF, Double Mountain Fork]

\begin{tabular}{|c|c|c|c|c|c|c|c|c|}
\hline $\begin{array}{c}\text { Sequence } \\
\text { number }\end{array}$ & $\begin{array}{l}\text { Station } \\
\text { number }\end{array}$ & $\begin{array}{l}\text { Station } \\
\text { name }\end{array}$ & $\begin{array}{l}\text { Period of } \\
\text { analyzed record }\end{array}$ & Latitude & Longitude & $\begin{array}{c}\text { Total } \\
\text { drainage } \\
\text { area } \\
\left(\mathrm{mi}^{2}\right) \\
\end{array}$ & $\begin{array}{c}\text { Contributing } \\
\text { drainage } \\
\text { area } \\
\left(\mathrm{mi}^{2}\right) \\
\end{array}$ & $\begin{array}{c}\text { Station used in } \\
\text { drought study by } \\
\text { Winters (2013) } \\
\text { (YES/no/--) }\end{array}$ \\
\hline 1 & 07299670 & Groesbeck Creek at SH 6 near Quanah, Tex. & $1963-2012$ & $34^{\circ} 21^{\prime} 16^{\prime \prime}$ & $99^{\circ} 44^{\prime} 24^{\prime \prime}$ & 303.0 & 303.0 & -- \\
\hline 2 & 07343000 & North Sulphur River near Cooper, Tex. & 1950-2012 & $33^{\circ} 28^{\prime} 29^{\prime \prime}$ & $95^{\circ} 35^{\prime} 15^{\prime \prime}$ & 276.0 & 276.0 & YES \\
\hline 3 & 07346070 & Little Cypress Creek near Jefferson, Tex. & $1947-2012$ & $32^{\circ} 42^{\prime} 46^{\prime \prime}$ & $94^{\circ} 20^{\prime} 45^{\prime \prime}$ & 675.0 & 675.0 & YES \\
\hline 4 & 08017200 & Cowleech Fork Sabine River at Greenville, Tex. & 1960-2012 & $33^{\circ} 07^{\prime} 58^{\prime \prime}$ & $96^{\circ} 04^{\prime} 36^{\prime \prime}$ & 81.0 & 81.0 & -- \\
\hline 5 & 08017300 & South Fork Sabine River near Quinlan, Tex. & 1960-2012 & $32^{\circ} 53^{\prime} 52^{\prime \prime}$ & $96^{\circ} 15^{\prime} 11^{\prime \prime}$ & 78.7 & 78.7 & -- \\
\hline 6 & 08029500 & Big Cow Creek near Newton, Tex. & $1953-2012$ & $30^{\circ} 49^{\prime} 08^{\prime \prime}$ & $93^{\circ} 47^{\prime} 08^{\prime \prime}$ & 128.0 & 128.0 & no \\
\hline 7 & 08041500 & Village Creek near Kountze, Tex. & 1940-2012 & $30^{\circ} 23^{\prime} 52^{\prime \prime}$ & $94^{\circ} 15^{\prime} 48^{\prime \prime}$ & 860.0 & 860.0 & YES \\
\hline 8 & 08068500 & Spring Creek near Spring, Tex. & 1940-2012 & $30^{\circ} 06^{\prime} 37^{\prime \prime}$ & $95^{\circ} 26^{\prime} 10^{\prime \prime}$ & 409.0 & 409.0 & YES \\
\hline 9 & 08070000 & East Fork San Jacinto River near Cleveland, Tex. & $1940-2012$ & $30^{\circ} 20^{\prime} 11^{\prime \prime}$ & $95^{\circ} 06^{\prime} 14^{\prime \prime}$ & 325.0 & 325.0 & YES \\
\hline 10 & 08070500 & Caney Creek near Splendora, Tex. & 1945-2012 & $30^{\circ} 15^{\prime} 34^{\prime \prime}$ & $95^{\circ} 18^{\prime} 08^{\prime \prime}$ & 105.0 & 105.0 & YES \\
\hline 11 & 08078000 & Chocolate Bayou near Alvin, Tex. & 1960-2012 & $29^{\circ} 22^{\prime} 09^{\prime \prime}$ & $95^{\circ} 19^{\prime} 14^{\prime \prime}$ & 87.7 & 87.7 & -- \\
\hline 12 & 08079600 & DMF Brazos River at Justiceburg, Tex. & $1963-2012$ & $33^{\circ} 02^{\prime} 18^{\prime \prime}$ & $101^{\circ} 11^{\prime} 50^{\prime \prime}$ & $1,466.0$ & 244.0 & -- \\
\hline 13 & 08082700 & Millers Creek near Munday, Tex. & 1964-2012 & $33^{\circ} 19^{\prime} 45^{\prime \prime}$ & $99^{\circ} 27^{\prime} 53^{\prime \prime}$ & 104.0 & 104.0 & -- \\
\hline 14 & 08084800 & California Creek near Stamford, Tex. & $1963-2012$ & $32^{\circ} 55^{\prime} 51^{\prime \prime}$ & $99^{\circ} 38^{\prime} 32^{\prime \prime}$ & 478.0 & 478.0 & -- \\
\hline 15 & 08101000 & Cowhouse Creek at Pidcoke, Tex. & $1951-2012$ & $31^{\circ} 17^{\prime} 05^{\prime \prime}$ & $97^{\circ} 53^{\prime} 05^{\prime \prime}$ & 455.0 & 455.0 & no \\
\hline 16 & 08115000 & Big Creek near Needville, Tex. & $1948-49,1953-2012$ & $29^{\circ} 28^{\prime} 35^{\prime \prime}$ & $95^{\circ} 48^{\prime} 45^{\prime \prime}$ & 42.8 & 42.8 & -- \\
\hline 17 & 08117500 & San Bernard River near Boling, Tex. & $1955-96,1998-2012$ & $29^{\circ} 18^{\prime} 48^{\prime \prime}$ & $95^{\circ} 53^{\prime} 37^{\prime \prime}$ & 727.0 & 727.0 & -- \\
\hline 18 & 08123800 & Beals Creek near Westbrook, Tex. & 1959-2012 & $32^{\circ} 11^{\prime} 57^{\prime \prime}$ & $101^{\circ} 00^{\prime} 49^{\prime \prime}$ & $9,802.0$ & $1,988.0$ & -- \\
\hline 19 & 08134000 & North Concho River near Carlsbad, Tex. & $1925-2012$ & $31^{\circ} 35^{\prime} 33^{\prime \prime}$ & $100^{\circ} 38^{\prime} 12^{\prime \prime}$ & $1,266.0$ & $1,191.0$ & YES \\
\hline 20 & 08150000 & Llano River near Junction, Tex. & 1916-92, 1998-2012 & $30^{\circ} 30^{\prime} 15^{\prime \prime}$ & $99^{\circ} 44^{\prime} 03^{\prime \prime}$ & $1,849.0$ & $1,854.0$ & YES \\
\hline 21 & 08150800 & Beaver Creek near Mason, Tex. & 1964-2012 & $30^{\circ} 38^{\prime} 36^{\prime \prime}$ & $99^{\circ} 05^{\prime} 44^{\prime \prime}$ & 215.0 & 215.0 & -- \\
\hline 22 & 08151500 & Llano River at Llano, Tex. & 1940-2012 & $30^{\circ} 45^{\prime} 04^{\prime \prime}$ & $98^{\circ} 40^{\prime} 10^{\prime \prime}$ & $4,197.0$ & $4,192.0$ & no \\
\hline 23 & 08153500 & Pedernales River near Johnson City, Tex. & 1940-2012 & $30^{\circ} 17^{\prime} 30^{\prime \prime}$ & $98^{\circ} 23^{\prime} 57^{\prime \prime}$ & 901.0 & 901.0 & no \\
\hline 24 & 08164000 & Lavaca River near Edna, Tex. & 1939-2012 & $28^{\circ} 57^{\prime} 35^{\prime \prime}$ & $96^{\circ} 41^{\prime} 10^{\prime \prime}$ & 817.0 & 817.0 & YES \\
\hline 25 & 08167500 & Guadalupe River near Spring Branch, Tex. & $1923-2012$ & $29^{\circ} 51^{\prime} 37^{\prime \prime}$ & $98^{\circ} 23^{\prime} 00^{\prime \prime}$ & $1,315.0$ & $1,315.0$ & YES \\
\hline 26 & 08171000 & Blanco River at Wimberley, Tex. & $1925,1929-2012$ & $29^{\circ} 59^{\prime} 39^{\prime \prime}$ & $98^{\circ} 05^{\prime} 19^{\prime \prime}$ & 355.0 & 355.0 & YES \\
\hline 27 & 08175000 & Sandies Creek near Westhoff, Tex. & $1931-34,1960-2012$ & $29^{\circ} 12^{\prime} 54^{\prime \prime}$ & $97^{\circ} 26^{\prime} 57^{\prime \prime}$ & 549.0 & 549.0 & -- \\
\hline 28 & 08186000 & Cibolo Creek near Falls City, Tex. & $1931-90,1992-2012$ & $29^{\circ} 00^{\prime} 50^{\prime \prime}$ & $97^{\circ} 55^{\prime} 48^{\prime \prime}$ & 827.0 & 827.0 & no \\
\hline 29 & 08189500 & Mission River at Refugio, Tex. & $1940-2012$ & $28^{\circ} 17^{\prime} 30^{\prime \prime}$ & $97^{\circ} 16^{\prime} 44^{\prime \prime}$ & 690.0 & 690.0 & YES \\
\hline 30 & 08190000 & Nueces River at Laguna, Tex. & $1924-2012$ & $29^{\circ} 25^{\prime} 42^{\prime \prime}$ & $99^{\circ} 59^{\prime} 49^{\prime \prime}$ & 737.0 & 737.0 & no \\
\hline 31 & 08190500 & West Nueces River near Brackettville, Tex. & 1940-1950, 1957-2012 & $29^{\circ} 28^{\prime} 52^{\prime \prime}$ & $100^{\circ} 14^{\prime} 21^{\prime \prime}$ & 694.0 & 694.0 & -- \\
\hline 32 & 08192000 & Nueces River below Uvalde, Tex. & $1940-2012$ & $29^{\circ} 07^{\prime} 25^{\prime \prime}$ & $99^{\circ} 53^{\prime} 40^{\prime \prime}$ & $1,861.0$ & $1,861.0$ & no \\
\hline 33 & 08195000 & Frio River at Concan, Tex. & $1925-29,1931-2012$ & $29^{\circ} 29^{\prime} 18^{\prime \prime}$ & $99^{\circ} 42^{\prime} 16^{\prime \prime}$ & 389.0 & 389.0 & YES \\
\hline 34 & 08196000 & Dry Frio River near Reagan Wells, Tex. & $1953-2012$ & $29^{\circ} 30^{\prime} 16^{\prime \prime}$ & $99^{\circ} 46^{\prime} 52^{\prime \prime}$ & 126.0 & 126.0 & -- \\
\hline 35 & 08198000 & Sabinal River near Sabinal, Tex. & 1943-2012 & $29^{\circ} 29^{\prime} 27^{\prime \prime}$ & $99^{\circ} 29^{\prime} 33^{\prime \prime}$ & 206.0 & 206.0 & YES \\
\hline 36 & 08200000 & Hondo Creek near Tarpley, Tex. & $1953-2012$ & $29^{\circ} 34^{\prime} 12^{\prime \prime}$ & $99^{\circ} 14^{\prime} 52^{\prime \prime}$ & 95.6 & 95.6 & -- \\
\hline 37 & 08205500 & Frio River near Derby, Tex. & $1916-2012$ & $28^{\circ} 44^{\prime} 11^{\prime \prime}$ & $99^{\circ} 08^{\prime} 40^{\prime \prime}$ & $3,429.0$ & $3,429.0$ & YES \\
\hline 38 & 08208000 & Atascosa River at Whitsett, Tex. & 1933-2006, 2008-12 & $28^{\circ} 37^{\prime} 19^{\prime \prime}$ & $98^{\circ} 16^{\prime} 52^{\prime \prime}$ & $1,171.0$ & $1,171.0$ & no \\
\hline
\end{tabular}




\section{Purpose and Scope}

The purpose of this report is (1) to describe the results of statistical tests for monotonic trends in annual mean streamflow statistics from natural and unregulated watersheds in Texas that were computed by using the nonparametric Kendall's tau statistical test to evaluate for independence with time or quantify whether statistically significant monotonic changes in a given streamflow statistic have occurred over time, and (2) to provide select summary statistics (L-moments) of the annual mean streamflow data that provide specific details of the "geometry" and "shape" of probability distributions of annual mean streamflow for streamgages where statistically significant trends in streamflow are not detected. Trend analyses and summary statistics for the 38 streamgages are provided. This report also provides an example application demonstrating how selected summary statistics (L-moments) of annual mean streamflow can be used to enhance the regional understanding of the magnitude and frequency of annual mean streamflow "events" (quantiles) through the use of a dimensionless regional frequency curve.

\section{Methods}

The underlying data for this investigation were daily mean streamflow for each station (365 or 366 values per year). USGS NWIS databases provided time series of annual mean streamflow for each of the streamgages. The dataset was restricted to the selected 38 long-term streamgages that each had a minimum of 49 years of cumulative record and were considered to be representative of natural and unregulated watershed conditions because they were coded in the NWIS database as recording peak streamflows that are not substantially affected (less than 10 percent of the CDA is controlled by dams and others structures that regulate streamflow). The streamgages were selectively screened for inclusion in this investigation from the overall USGS streamgage network in Texas based on information or foreknowledge of Texas hydrology obtained from prior USGS studies (Asquith and Slade, 1997; Lanning-Rush, 2000; Slade and others, 2001). The data for this investigation encompass the period of available record of annual mean streamflow. Many of the 38 streamgages included in this study have gaps in their records as listed in table 1 . The gaps are illustrated in figure 2 where the sequence numbers listed in table 1 provide streamgage identification. Gaps in record can result from disruptions in the cooperative agreements between the USGS and the Federal, State, and local cooperators that share responsibility for operation of the streamgage. Major roadway construction also can disrupt continuous operation because streamgages often are located on bridges and along roads and highways.

There were other qualified long-term streamgages that were not included in this report because substantial cross correlation in the streamflow measured at these streamgages with the streamflow measured at other streamgages on the same stream is either likely or has been previously documented (Slade and others, 2001). For example, if two long-term streamgages reside on the same stream course and are comparatively close to each other (distance not defined but rather based on ad hoc considerations including the size of the watershed upstream from the gage), then their records lack statistical independence.

The nonparametric Kendall's tau statistical test was used to detect monotonic trends in annual mean streamflow over time (Hollander and Wolfe, 1973; Helsel and Hirsch, 2002). Specifically, the test uses the relation between time and ranked streamflow, rather than streamflow magnitude, for computations; thus, the trend analyses in this report (unless otherwise noted) refer to the direction but not the magnitude of streamflow change. A statistically significant positive Kendall's tau value indicates an upward streamflow trend; conversely, a statistically significant negative tau indicates a downward streamflow trend. The probability value (p-value) of Kendall's tau is a measure of the statistical significance of the trend assuming a null hypothesis that no trend is present. For this investigation, a p-value less than 0.02 indicated the presence of a statistically significant trend (alpha $=0.02$ ); conversely, a p-value greater than 0.02 indicated the absence of a statistically significant trend. If an inquiry into the actual direction of the trend was needed, then the p-values required a division by 2 because the Kendall's tau statistical test is inherently a two-tailed test.

To compute the Kendall's tau statistics and p-values, the $\mathrm{R}$ environment for statistical computing ( $\mathrm{R}$ Development Core Team, 2012) was used. Specifically, the R function cor.test (..., method="kenda 11 "), and its associated features were used. The documentation within the $\mathrm{R}$ environment provides further information. Generally, if trends are apparent, they might be caused by factors such as (1) landscape and land-use modifications and changes, (2) changes in groundwater gains or losses, (3) surfacewater use and return flows from facilities such as municipal wastewater treatment plants, and (4) potential trends in precipitation patterns and other general climatic shifts, cycles, and changes.

When monotonic trends in annual mean streamflow were detected, the nonparametric Theil slope of the streamflow was used to quantify change in streamflow in cubic feet per second per year. The Theil slope is a nonparametric estimate of a regression slope of annual mean streamflow with time. The Theil slope is defined as the median of all unique pairwise slopes (there are $n \bullet(n-1) / 2$ unique slopes, with $n$ being the record length) from the available record for an individual streamgage (Hollander and Wolfe, 1973, p. 205-206).

L-moments (Hosking, 1990) are especially suitable for estimation of the parameters of probability distributions (Hosking and Wallis, 1997; Asquith, 2011). A fitted probability distribution facilitates the extrapolation to 


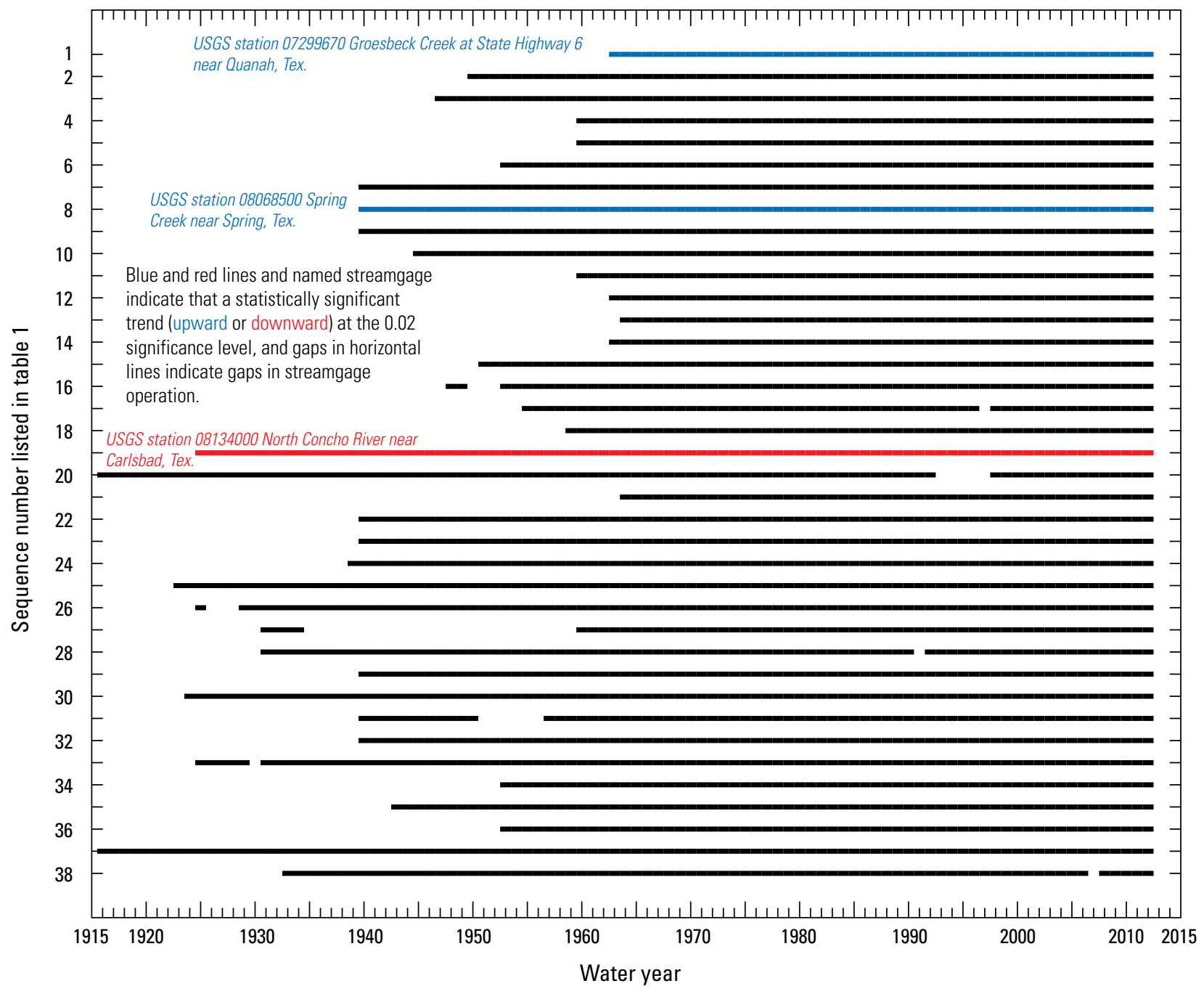

Figure 2. Comparison of periods of operation for 38 selected long-term U.S. Geological Survey (USGS) streamgages in Texas by sequence number listed in table 1 and identification of three stations with a statistically significant trend in annual mean streamflow by the nonparametric Kendall's tau statistical test.

extreme and otherwise rare low- or high-flow conditions or events outside or beyond the available length of record (Hosking and Wallis, 1997). L-moments have been successfully used for regional assessment of the magnitude and frequency of various hydrometeorological phenomena in Texas (Asquith, 2001; Asquith and Roussel, 2004; Asquith and others, 2006; Asquith and Roussel, 2009). A general overview of regionalization in hydrology is provided by Stedinger and others (1993). Selected summary statistics of annual mean streamflow (L-moments) for the 35 streamgages for which no trends in streamflow were detected. The sample variances for the L-moments of each streamgage also were estimated by bootstrap resampling (Verzani, 2005; Rizzo, 2008; Ugarte and others, 2008). These sampling variances were subsequently used to compute inverse-variance, weighted mean values of each of the L-moments. The weighted mean values of the L-moments represent "regional expectations" for the study area.

\section{Trend Analysis and Selected Summary Statistics of Annual Mean Streamflow}

This section (1) summarizes the trend analysis of annual mean streamflow supported by Kendall's tau, (2) reports a nonparametric Theil slope of the streamflow change per year for streamgages having statistically significant trends, and (3) presents selected summary statistics of annual mean streamflow for the 35 streamgages for which Kendall's tau did not detect a statistically significant trend in streamflow for the period of record. Because published graphical and tabular 
depictions of streamflow time series information in Texas are readily available (Asquith and others, 2007a, b; Asquith and Heitmuller, 2008; Winters 2013), and because time series graphics and tables can now be produced with ease by using the NWISWeb interface, graphical depictions of streamflow time series are not presented in this report.

\section{Trend Analysis of Annual Mean Streamflow}

A summary of the Kendall's tau analysis for each of the 38 streamgages is listed in table 2 . The results of the analysis show that the majority of the streamgages do not have statistically significant trends with respect to annual mean streamflow. In other words, the general annual volumetric production of surface water from the corresponding watersheds appears to have not appreciably changed during the respective periods of record for the individual streamgages. Such an observation does not mean that one or more parts of the hydrologic spectrum, such as flood peaks or annual minimum streamflows, are themselves "trendless."

Three stations have statistically significant trends. The monotonic trend analysis detected 2 statistically significant upward trends ( 0.01 one-tail significance), 1 statistically significant downward trend ( 0.01 one-tail significance level), and 35 instances of no statistically significant trend $(0.02$ two-tailed significance level). Figure 2 identifies the three streamgages that had statistically significant trends in annual mean streamflow. These results were not surprising given that the streamgages were screened to include only those where the streamflow was thought to be natural and unregulated for the entire period of record at each station. Possible effects from potential long-term changes in groundwater levels along the stream channel or any changes in precipitation amounts over time were not considered.

Theil slopes for the three streamgages for which statistically significant trends in streamflow were identified are as follows: station 07299670 has an estimated increase of +0.40 cubic feet per second $\left(\mathrm{ft}^{3} / \mathrm{s}\right)$ per year, station 08068500 has an estimated increase of $+2.72 \mathrm{ft}^{3} / \mathrm{s}$ per year, and station 08134000 has an estimated decrease of $-0.24 \mathrm{ft}^{3} / \mathrm{s}$ per year.

The Theil slope values are listed in table 2 .

Although not statistically significant, the results in table 2 show that a positive Kendall's tau value was determined for 25 of the 35 streamgages for which no trend was detected. The binomial test (Hollander and Wolfe, 1973, p. 15-22) was used to assess the likelihood of such a high number of positive values for Kendall's tau and to assess if there were an equal likelihood of numerically negative or positive values in the absence of any streamflow trends. If 25 were considered the "number of successes" from a sample size of
35 with an anticipated probability of 0.5 , the binomial test, which was performed by using the binom. test () function with the respective arguments from the $\mathrm{R}$ environment (25, $35, p=0.5$ ), yields a $p$-value of 0.02 . This also is a small $\mathrm{p}$-value and not related to the alpha value of 0.02 used to assign statistical significance for the Kendall's tau tests. Thus, it may be concluded that there is a statistically significant likelihood that in aggregate, annual mean streamflow has increased slightly to an undocumented degree for 25 of the 35 streamgages although these 25 streamgages individually do not have statistically significant trends. Furthermore, analysis of long-term statewide precipitation totals could be made to bolster (or counter) the finding of a statistically significant likelihood that in aggregate, the annual mean streamflow has increased slightly for 25 of the 35 streamgages for which individual trends were not detected.

\section{Selected Summary Statistics of Annual Mean Streamflow}

This section describes selected summary statistics (L-moments) and sampling variances from replacementbootstrap simulation for the 35 streamgages that individually lack statistically significant trends. These statistics of annual mean streamflow for each streamgage represent a collection of different numerical values that together describe the location, scale, and various metrics of the shape of the observed data.

Logarithmic transformations are commonly used in statistical analyses of streamflow data (Stedinger and others, 1993). For example, logarithmic transformations of strictly positive hydrologic data are done to avoid conditional probability adjustment for the zero values; values equal to zero must be offset to avoid using a logarithm of zero. A mathematical benefit of using logarithmic transformation is that probability distributions with infinite lower and upper limits become applicable. Logarithmic transformations of annual mean streamflows at each of the 35 unregulated streamgages were done to compute summary statistics that have utility in other applications. An arbitrary value of $10 \mathrm{ft}^{3} / \mathrm{s}$ was added to the streamflows for each of the 35 streamgages lacking statistically significant trends prior to logarithmic transformation to accommodate mean annual streamflows equal to zero (no flow). These data are referred to as the "offset annual mean streamflow." The offsetting along the real-number line permits direct use of logarithmic transformations without the added complexity of conditional probability adjustment for zero values in magnitude and frequency analyses (Hosking and Wallis, 1997, p. 151-152; Asquith, 2011, p. 283-285). 
Table 2. Summary of mean annual streamflow, Kendall's tau and associated p-value (probability value), and declaration of statistical significance with respect to trend direction for the selected long-term U.S. Geological Survey streamgages in Texas.

$\left[\mathrm{ft}^{3} / \mathrm{s}\right.$, cubic feet per second; $\mathrm{p}$-value, probability value; --, not applicable because trend detected; (number), indicates the Theil slope in cubic feet per second per year]

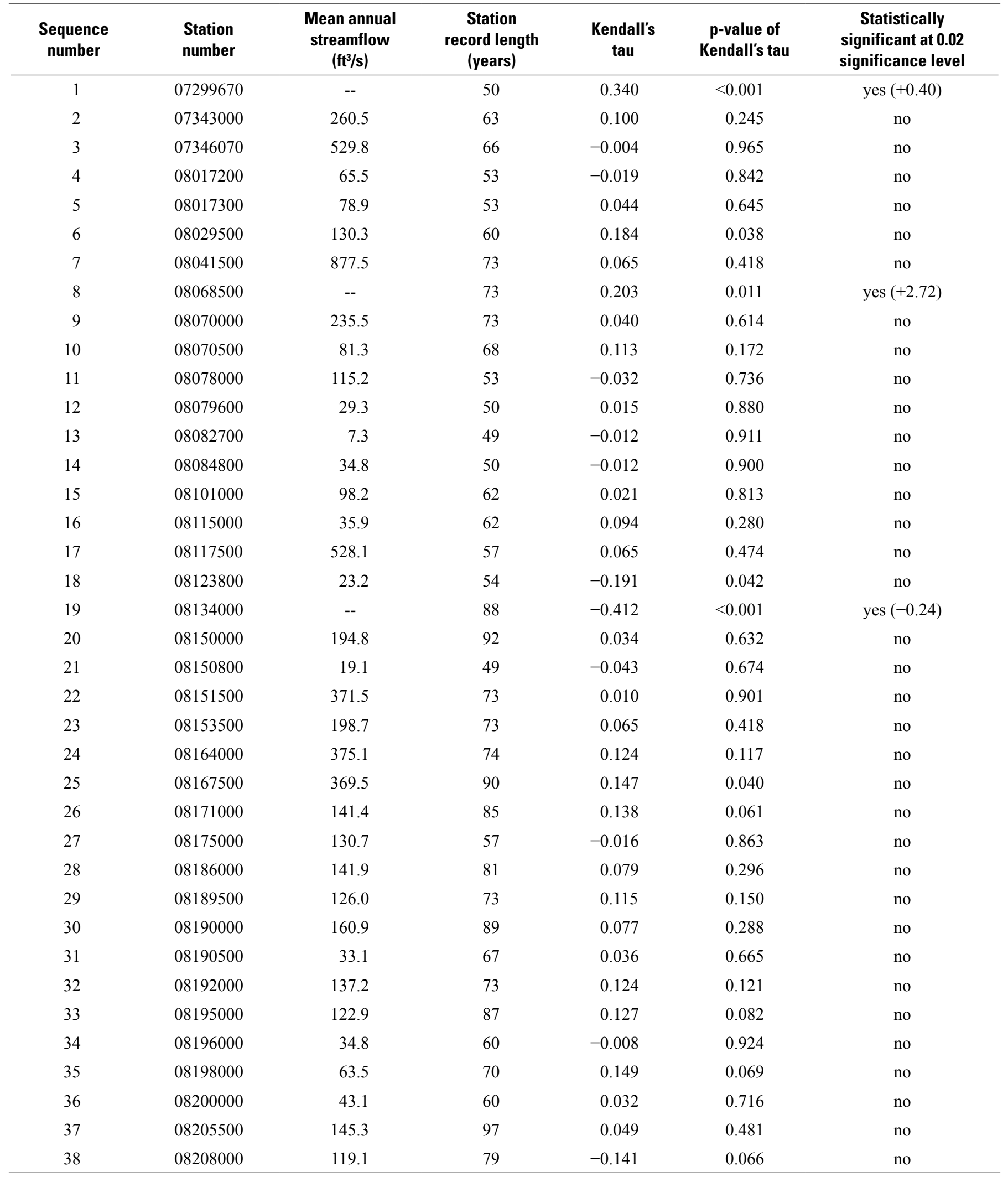


L-moments are a type of statistic used to quantify the location, scale, and shape of probability distributions (Hosking, 1990; Hosking and Wallis, 1997; Asquith, 2011). The first six sample L-moments of the base-10 logarithms of the offset annual mean streamflow were computed by using the 1 moms (..., nmom=6) function in the lmomco package for $\mathrm{R}$ by Asquith (2013). To clarify, the $\mathrm{nmom}=6$ in the argument to the 1 moms () function is a command to $\mathrm{R}$ to compute the first six L-moments. The sample L-moments are listed in table 3. The L-moments are not listed for the three streamgages for which statistically significant trends were detected because of a concern that the year-over-year distribution of the data shows a monotonic trend. The columns titled "L-scale" and "L-CV" can each be computed from the other by the equation $\mathrm{L}-\mathrm{CV}=\mathrm{L}$-scale / mean, where L-scale is analogous (but not numerically equivalent) to standard deviation, and L-CV is the coefficient of L-variation (table 3). Viglione (2010, p. 2231) provides the following explanation of the L-CV coefficient and its utility in hydrologic studies:

$* * *$ the sample coefficient of variation $(\mathrm{CV})$, that is, the ratio of standard deviation to the mean of a series of data, exhibits substantial bias and variance when samples are small or belong to highly skewed populations (Vogel and Fennessey, 1993). This is the problem that is normally encountered in hydrology when dealing with floods or extreme rainfall events. The coefficient of L-variation (L-CV) is another-more efficient in many cases - measure of data dispersion introduced by Hosking (1990). It has hence replaced the conventional $\mathrm{CV}$ in various applications of statistical hydrology.

The sampling variances of each corresponding L-moment were used to compute regional or study-area values for the L-moments through weighted mean computation. Wang and Hutson (2013) describe an exact analytical bootstrap method for computation of sampling variance of L-moments. Unfortunately, the available years of record for each of the 35 streamgages is so large as to produce severe numerical problems in matrices in their method. In order to compute sampling variances for each of the sample L-moments for each streamgage, replacement bootstrap simulation was done by using the sample $(\ldots$, replace=TRUE $)$ function in R, which shows that replacement sampling was used. For estimation of the sampling variance, 10,000 replications for the corresponding sample size for each streamgage were used. An overview of bootstrap simulation is found in Rizzo (2008, p. 183-190), Ugarte and others (2008), and Verzani (2005). The documentation within the $\mathrm{R}$ environment provides further information. For each bootstrap sampling, the first six L-moments were retained, and subsequently the variances of the 10,000 replicates of each of the six L-moments were computed. These sampling variances of the L-moments are listed in table 3 .
The following values represent the weighted means of the L-moments (the regional L-moments) found by using the inverse of their respective variances as weight factors: mean $=1.9679$, L-scale $=0.1706, \mathrm{~L}-\mathrm{CV}=0.0857$, L-skew $=-0.0200$, L-kurtosis $=0.0759$, Tau $5=-0.0030$, and Tau6 $=0.0264$. In turn, these regional L-moments can provide a basis for parameter estimation of a probability distribution to model the magnitude and frequency of annual mean streamflow as described by the example in the section that follows.

\section{An Example Application of Regional Analysis of Annual Mean Streamflow Frequency}

An example application of the L-moments listed in table 3 is provided in this section. In this example, the regional L-moments of annual mean streamflow in Texas are used to quantify the scale and shape of a dimensionless regional probability distribution. The adjective "regional" indicates that the weighted mean L-moments for the region loosely defined by the spatial scale that is congruent with the locations of the 35 streamgages and the respective watersheds for each streamgage. The structure of the probability distribution (Hosking and Wallis, 1997) is useful in regional magnitude and frequency analyses (Asquith and Roussel, 2009). The 4-parameter asymmetric exponential power (AEP) distribution was chosen from more than 20 possible distribution candidates (Asquith, 2011, 2013). The AEP distribution and its L-moments are thoroughly described by Asquith (2014). The mathematical definitions for the AEP distribution are complex and are not listed in this report because they are not directly germane to the example application. The AEP distribution best reproduces the dimensionless regional L-moments with the minor change of setting the mean to unity and setting the regional L-scale to equal the $\mathrm{L}-\mathrm{CV}$, which removes dimension from the distribution (Hosking and Wallis, 1997). The dimensionless regional L-moments, which are used to fit the AEP, are mean $=1, \mathrm{~L}$-scale $=0.0857$, L-skew $=-0.0200$, and L-kurtosis $=0.0759$.

The parameters for the dimensionless regional AEP distribution defined per nomenclature of Asquith (2014) are $x i=1.028$ (location parameter), alpha $=0.245$ (scale parameter), kappa $=1.121$ (shape parameter), and $h=3.064$ (shape parameter). These parameters can be written in short hand as $\operatorname{AEP}(1.028,0.245,1.121,3.064)$ or alternatively as $\mathrm{AEP}(\Theta r$ reg $)$ where $\Theta$ is a vector of the four parameters. This alpha parameter nomenclature is the same as the nomenclature of Asquith (2014) and elsewhere in L-moment literature for scale parameters (Hosking and Wallis, 1997) but is not the same as the statistical significance level defined in the context of Kendall's tau. 
Table 3. Summary of first six L-moments of base-10 logarithms of offset annual mean streamflow and sampling variances computed by bootstrap simulation of 10,000 replications for the selected long-term U.S. Geological Survey streamgages in Texas.

[ft³/s, cubic feet per second; log, base-10 logarithm; “10”, 10 cubic feet per second added; L-CV, coefficient of L-variation (L-scale/mean); L-skew, L-moment measurement of skew; L-kurtosis, L-moment measurement of kurtosis; Tau5, unnamed L-moment; Tau6, unnamed L-moment; --, not applicable because trend detected]

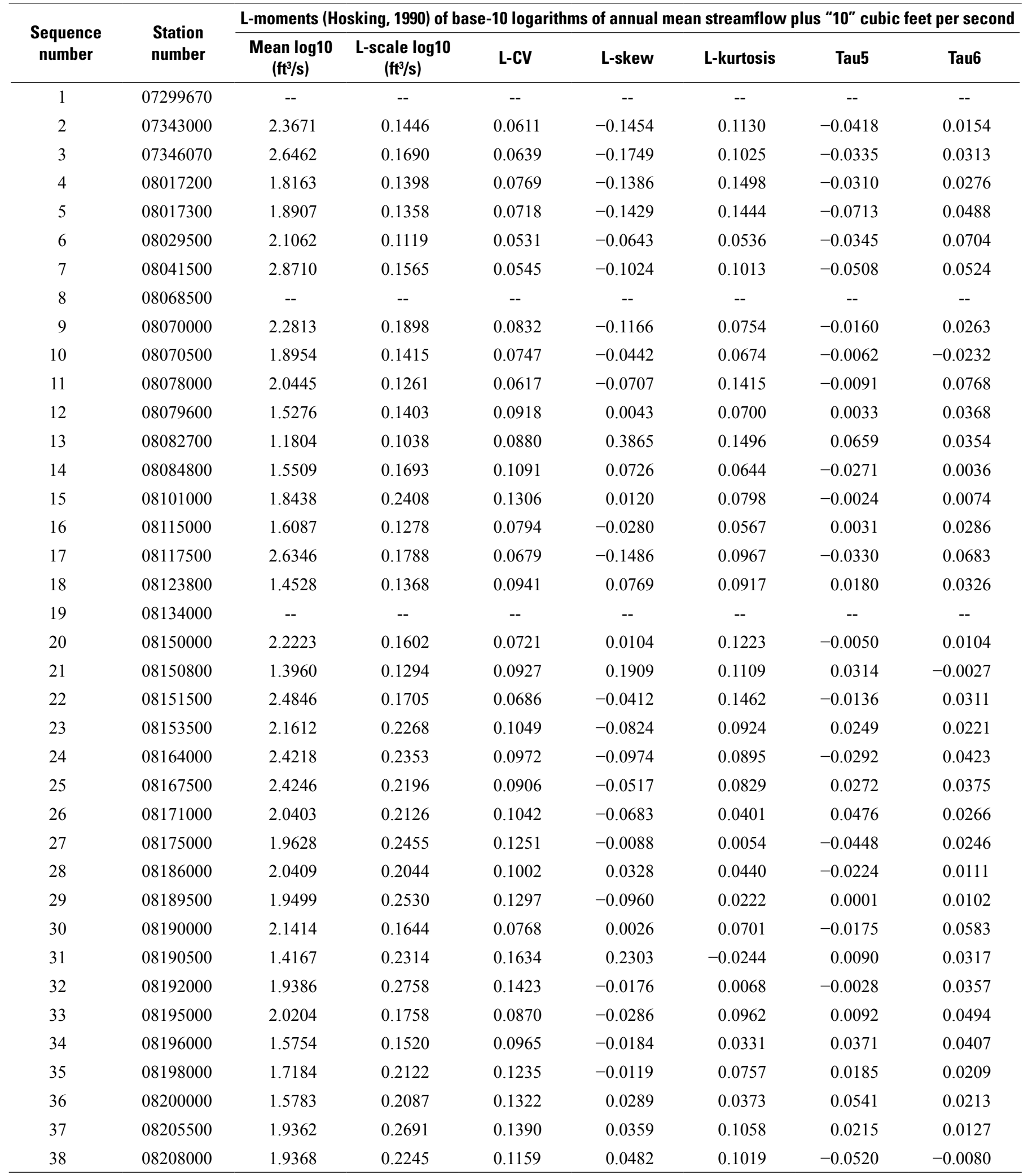


Table 3. Summary of first six L-moments of base-10 logarithms of offset annual mean streamflow and sampling variances computed by bootstrap simulation of 10,000 replications for the selected long-term U.S. Geological Survey streamgages in Texas.-Continued

[fts/s, cubic feet per second; log, base-10 logarithm; “10", 10 cubic feet per second added; L-CV, coefficient of L-variation (L-scale/mean); L-skew, L-moment measurement of skew; L-kurtosis, L-moment measurement of kurtosis; Tau5, unnamed L-moment; Tau6, unnamed L-moment; --, not applicable because trend detected]

\begin{tabular}{|c|c|c|c|c|c|c|c|c|}
\hline \multirow{2}{*}{$\begin{array}{c}\text { Sequence } \\
\text { number }\end{array}$} & \multirow{2}{*}{$\begin{array}{l}\text { Station } \\
\text { number }\end{array}$} & \multicolumn{7}{|c|}{ Sampling variances of the L-moments shown to left multiplied by 1,000} \\
\hline & & Mean & L-scale & L-CV & L-skew & L-kurtosis & Tau5 & Tau6 \\
\hline 1 & 07299670 & -- & -- & -- & -- & -- & -- & -- \\
\hline 2 & 07343000 & 1.0268 & 0.1744 & 0.0365 & 2.1661 & 1.6174 & 0.9672 & 0.6098 \\
\hline 3 & 07346070 & 1.3654 & 0.2262 & 0.0391 & 2.3555 & 1.3247 & 0.7549 & 0.6181 \\
\hline 4 & 08017200 & 1.1728 & 0.2143 & 0.0782 & 2.8796 & 2.0802 & 1.3552 & 0.9856 \\
\hline 5 & 08017300 & 1.1371 & 0.2140 & 0.0719 & 3.4830 & 2.0398 & 1.6238 & 1.4941 \\
\hline 6 & 08029500 & 0.6316 & 0.0762 & 0.0189 & 3.8768 & 1.5516 & 1.0166 & 0.6671 \\
\hline 7 & 08041500 & 1.0071 & 0.1705 & 0.0234 & 2.8065 & 1.4442 & 0.8783 & 0.7308 \\
\hline 8 & 08068500 & -- & -- & -- & -- & -- & -- & -- \\
\hline 9 & 08070000 & 1.4934 & 0.1998 & 0.0466 & 2.2141 & 1.1906 & 0.5595 & 0.3963 \\
\hline 10 & 08070500 & 0.8874 & 0.0991 & 0.0303 & 1.6456 & 1.4558 & 0.8203 & 0.3316 \\
\hline 11 & 08078000 & 0.9281 & 0.1615 & 0.0425 & 4.0349 & 1.5851 & 1.1388 & 0.9835 \\
\hline 12 & 08079600 & 1.1544 & 0.1376 & 0.0637 & 3.6910 & 2.0659 & 0.9786 & 0.7691 \\
\hline 13 & 08082700 & 0.8264 & 0.2289 & 0.1219 & 3.6585 & 3.3076 & 2.7468 & 2.1709 \\
\hline 14 & 08084800 & 1.7267 & 0.1965 & 0.0745 & 3.2731 & 2.3122 & 1.2978 & 1.4558 \\
\hline 15 & 08101000 & 2.7620 & 0.3206 & 0.1068 & 2.1669 & 1.3869 & 0.6844 & 0.5098 \\
\hline 16 & 08115000 & 0.7691 & 0.0835 & 0.0362 & 2.7020 & 1.1507 & 0.7239 & 0.6441 \\
\hline 17 & 08117500 & 1.7246 & 0.3042 & 0.0534 & 3.9754 & 2.1005 & 1.3182 & 0.9087 \\
\hline 18 & 08123800 & 1.0524 & 0.1411 & 0.0612 & 3.0657 & 1.6648 & 0.9377 & 0.7602 \\
\hline 19 & 08134000 & -- & -- & -- & -- & -- & -- & -- \\
\hline 20 & 08150000 & 0.8529 & 0.1245 & 0.0264 & 1.4044 & 1.0512 & 0.5321 & 0.2925 \\
\hline 21 & 08150800 & 1.0801 & 0.1841 & 0.0732 & 2.7521 & 2.6873 & 1.8102 & 0.9666 \\
\hline 22 & 08151500 & 1.2067 & 0.2080 & 0.0358 & 2.0595 & 1.1255 & 0.6208 & 0.6459 \\
\hline 23 & 08153500 & 2.1687 & 0.2844 & 0.0779 & 2.1140 & 1.3178 & 0.7534 & 0.6204 \\
\hline 24 & 08164000 & 2.2616 & 0.3319 & 0.0707 & 2.3964 & 1.2519 & 0.6907 & 0.4730 \\
\hline 25 & 08167500 & 1.5916 & 0.2124 & 0.0426 & 2.0788 & 1.2042 & 0.6125 & 0.3990 \\
\hline 26 & 08171000 & 1.5763 & 0.1581 & 0.0498 & 2.1868 & 1.1581 & 0.5061 & 0.3648 \\
\hline 27 & 08175000 & 3.0348 & 0.2415 & 0.0779 & 3.6633 & 1.3895 & 0.7950 & 0.7083 \\
\hline 28 & 08186000 & 1.5259 & 0.1565 & 0.0369 & 2.0421 & 1.2120 & 0.4957 & 0.4288 \\
\hline 29 & 08189500 & 2.6382 & 0.2358 & 0.0953 & 2.4360 & 1.0608 & 0.5439 & 0.3429 \\
\hline 30 & 08190000 & 0.9267 & 0.1106 & 0.0249 & 2.1805 & 0.7747 & 0.4459 & 0.3389 \\
\hline 31 & 08190500 & 2.5717 & 0.2882 & 0.0669 & 4.4999 & 1.3656 & 0.8441 & 0.4138 \\
\hline 32 & 08192000 & 2.9885 & 0.2324 & 0.0819 & 2.7588 & 0.7720 & 0.5253 & 0.3627 \\
\hline 33 & 08195000 & 1.0649 & 0.1533 & 0.0404 & 2.0701 & 0.8579 & 0.4403 & 0.3310 \\
\hline 34 & 08196000 & 1.1160 & 0.1035 & 0.0476 & 3.2074 & 1.1673 & 0.6816 & 0.4747 \\
\hline 35 & 08198000 & 1.8678 & 0.2225 & 0.0863 & 2.2118 & 1.1697 & 0.5825 & 0.4580 \\
\hline 36 & 08200000 & 2.1613 & 0.2098 & 0.0895 & 3.0601 & 1.3689 & 0.5828 & 0.4964 \\
\hline 37 & 08205500 & 2.2598 & 0.3152 & 0.0847 & 1.3356 & 0.8439 & 0.4872 & 0.2727 \\
\hline 38 & 08208000 & 1.9158 & 0.2591 & 0.0692 & 1.5705 & 1.5771 & 0.6733 & 0.4149 \\
\hline
\end{tabular}


The theoretical L-moments for $\mathrm{AEP}(\Theta r e g)$ fit to the regional L-moments (Asquith, 2014) are mean $=1$, L-scale $=0.0857, \mathrm{~L}-\mathrm{CV}=0.0857, \mathrm{~L}-\mathrm{skew}=-0.0200, \mathrm{~L}-$ kurtosis $=$ 0.0759 , Tau $5=-0.00480$, and Tau $6=0.0297$. A comparison of these theoretical L-moments to the regional L-moments used to fit the AEP indicates that the AEP is a suitable distribution because of the "closeness" and "correct sign" of Tau5 (the 5th L-moment) ( -0.0030 compared to -0.00480$)$ as well as Tau6 (0.0264 compared to 0.0297). The fifth and sixth AEP L-moments are almost identical to the regional L-moments even though the AEP has just four parameters and directly fits the first four L-moments but also well approximates the fifth and sixth L-moments, which justifies the choice of the AEP over alternative 4-parameter distributions such as the kappa distribution (Hosking and Wallis, 1997; Asquith, 2011; Karian and Dudewicz, 2010) and the generalized lambda distributions (Asquith, 2011, 2014; Karian and Dudewicz, 2010). In fact, although the regional AEP in this instance comprises just four parameters, it achieves a remarkable degree of fit through the sixth regional L-moment.

By using the lmomco software package described by Asquith (2013), an AEP(1.028, 0.245, 1.121, 3.064) of the regional distribution can be solved for a given nonexceedance probability ( 0.75 or the 75 th percentile) with the following $\mathrm{R}$ code sequence:

1ibrary (7momco)

AEP <- c $(1.028,0.245,1.121,3.064)$

Q75 <- quaaep4(0.75, vec2par(AEP, type="aep4"))

The 75th percentile (Q75) is about 1.11 (dimensionless).

The probability density function (PDF) of the regional AEP $(\Theta r e g)$ distribution is shown in the inset in figure 3 as the dashed red line. Inspection of the PDF in the figure inset shows that the regional AEP distribution has slight asymmetry of about 1 (unity) and a flatter central part than that for the site-specific PDF. If the original data were lognormally distributed, then their logarithms would be normally distributed and thus would plot as a nearly straight line on a logarithmic (vertical axis) and probability (horizontal axis) plot. The frequency curves in figure 3 indicate that the data for the long-record streamgages have inherent deviance from the log-normal distribution.

The average number of years of record (about 69 years) for the 35 streamgages lacking trends in streamflow in Texas can be used as a weight factor in combining the regional

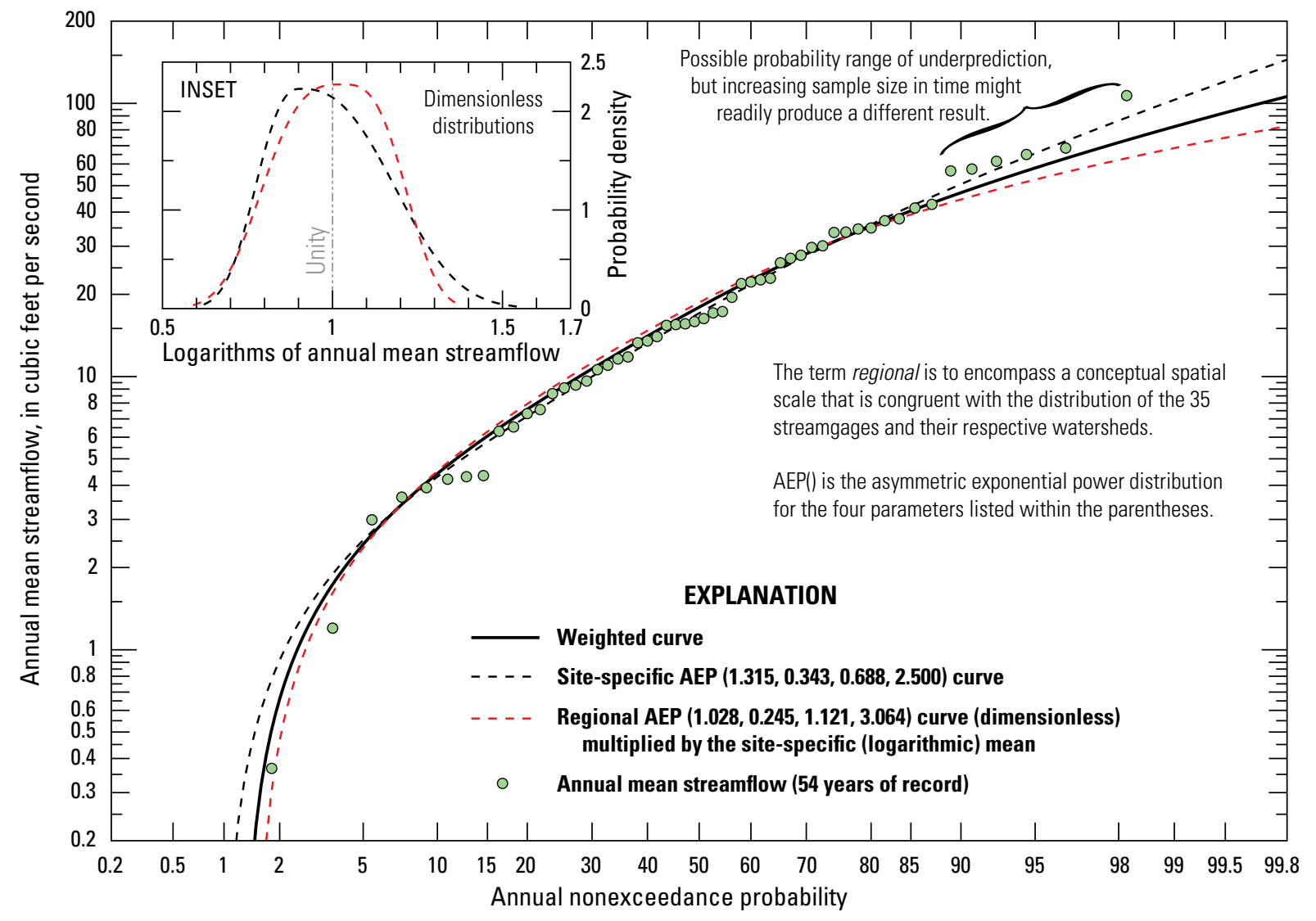

Figure 3. Comparison of three annual mean frequency curves in probability-density (inset) and quantile-function (main plot) form for U.S. Geological Survey streamgage 08123800 Beals Creek near Westbrook, Texas (table 1), associated with example application. 
AEP distribution with a site-specific distribution from the observed annual mean streamflow data for a given streamgage. A weighted-frequency curve could enhance the reliability of regional annual mean streamflow frequency analysis for other streamgages in Texas as well as those in this investigation.

For the simplified analysis for this example, the regional AEP distribution is assumed applicable throughout the study area. A more refined analysis following Hosking and Wallis (1997) guidelines might consider the potential for smaller regions of similar rainfall, topography, geology, and other potential factors; or the analysis might provide for systematic explanation of regional (that is, spatial) variation in the frequency curve attributable to potential explanatory variables as listed.

Weighted-frequency analysis recognizes that the available record for most streamgages other than those for this investigation is comparatively short for reliable distaltail (extreme, and therefore rare, low- and high-streamflow) estimation. Weighted-frequency analysis incorporates the blending of a regional frequency curve with a site-specific curve that is based on the available data at a particular streamgage. A general algorithm for weighted-frequency analysis based on the AEP $(\Theta r e g)$ can be derived that hydrologists and engineers might find useful for investigating the annual mean streamflow in Texas for unregulated watersheds. The steps for using the algorithm with the data from a given streamgage in an unregulated watershed are as follows:

1. Acquire the annual mean streamflow data $(X)$ in cubic feet per second for the selected streamgage and record the length of record $(m)$ for a later step;

2. Add $10 \mathrm{ft}^{3} / \mathrm{s}$ (an arbitrary value) to the annual mean streamflow data as protection against the potential for zero-flow annual values in step 1: $X+10$;

3. Compute the base-10 logarithmic transformation of the offset annual mean streamflow data in step 2: $X=\log _{10}(X+10)$;

4. Compute the first six L-moments (mean through Tau6, [7moms (X, nmom=6)], Asquith [2013]) of the data in step 3 and particularly record the "site-specific mean" $(\mathrm{mu})$ for a later step;

5. (Optionally perform a subtask of candidate distribution evaluation and use the chosen distribution). Fit the AEP or other distribution to the L-moments (this is known as the method of L-moments [Hosking, 1990; Asquith, 2011]) computed in step 4 to create a site-specific frequency curve and let this distribution be known as $S$;

6. Let $R$ be the regional annual mean frequency curve computed from AEP $(\Theta r e g)$ multiplied by the site-specific mean $m u$ of step 4;
7. Compute a weighted combination $Q$ of the dimensionless distributions for nonexceedance probabilities or quantiles of interest better stated as the straightforward proration $Q=(m S+69 R) /(m+69)$, and note that $Q$ remains in logarithmic space;

8. Detransform the frequency curve in step 7: $Q=10^{Q}$;

9. Subtract $10 \mathrm{ft}^{3} / \mathrm{s}: Q=Q-10$; and lastly

10. Set all negative values to zero, which is an ad hoc truncation to physical constraints, by using a vector operation that all $Q[Q<0]=0$.

Quantiles of interest in step 7 might be, for example, the 0.02 annual nonexceedance probability that represents a year of drought or a 0.98 annual nonexceedance probability that represents streamflow during a water year having abundant rainfall relative to long-term climatic expectations. For graphical purposes, a sequence of quantiles for nonexceedance probabilities between say 0.01 and 0.99 in increments of 0.01 would be useful to draw smoothly varying frequency curves.

An example application of the algorithm used with USGS streamgage 08123800 Beals Creek near Westbrook, Tex., is shown in figure 3 , in which the 54 years of annual mean streamflow data for this streamgage are depicted.

The site-specific AEP or $S$ (step 5 of the algorithm) fit by L-moments of the offset base- 10 logarithms is $\operatorname{AEP}(1.315,0.343,0.688,2.500)$. The site-specific L-moments are mean $=1.4528, \mathrm{~L}$-scale $=0.1368, \mathrm{~L}-\mathrm{CV}=0.0941$, L-skew $=0.0769$, L-kurtosis $=0.0917$, Tau5 $=0.0180$, and Tau6 $=0.0326$ (table 3 ). The site-specific frequency curve $S$ is shown as the dashed black line in figure 3 as well as its dimensionless PDF (mean $=1$, L-scale $=0.0941$ ) in the inset. As anticipated, $S$ closely approximates the actual distribution of the 54 observed values.

The offset base-10 logarithmic mean of the streamflow data for USGS streamgage 08123800 Beals Creek near Westbrook, Tex., is 1.452 , so $R$ is 1.452 multiplied by AEP $(\Theta r e g)$ (table 3$)$. The resulting regional frequency curve or $R$ (step 6 of the algorithm) is shown as the dashed red line in figure 3 as well as its dimensionless PDF (dimensionless meaning that the mean $=1$, L-scale $=0.0857$ ) in the inset.

Comparison of the PDFs in the inset in figure 3 shows that the two PDFs are reasonably similar to each other. The dashed black line results from 54 years of data, whereas the dashed red line results from a total of 2,375 total years of data (albeit not all of the individual years are truly independent of the others).

Regional information about the geometry and shape of annual mean streamflow from other streamgages in Texas can be incorporated into the algorithm. The weighted-frequency curve $Q$ (step 10 of the algorithm) is shown as the black line in figure 3 and clearly resides between the two dashed curves as expected. The weighed frequency curve might provide preferable quantile estimation for years with extremely rare annual mean streamflow because of the inclusion or pooling of information from the 35 long-term streamgages that lack statistically significant trends in annual mean streamflow. 
The enumerated steps related to the example application just described are an overview of a relatively simplified method for estimating mean streamflow frequency. The result is an outline of a technique that hydrologists and engineers might find useful for evaluating annual mean streamflow in Texas for unregulated watersheds; for example, the dimensionless regional frequency curve shown in figure 3 (when multiplied by the estimated mean annual streamflow from the equations by Lanning-Rush [2000]) could be used to evaluate the magnitude and frequency of annual mean streamflow. The example application uses a single regional frequency curve for illustration purposes. By incorporating additional variables to account for spatial variation in rainfall (variation in mean annual precipitation for instance), topography, geology, and other factors that influence the magnitude and frequency of annual mean streamflow, the reliability of the method described in this report could be enhanced (Hosking and Wallis, 1997; Nuñez and others, 2011).

\section{Summary}

In 2013, the U.S. Geological Survey (USGS) operated more than 500 continuous streamgages (streamflow-gaging stations) in Texas. In cooperation with the Texas Water Development Board, the USGS evaluated mean annual streamflow data for 38 selected streamgages that were active as of water year 2012. The 38 streamgages have annual mean streamflow data anticipated to be representative of watersheds through 2013 that can be considered natural and unregulated. Long-term streamflow data representative of natural and unregulated watershed conditions are useful for evaluation of changes (trends) in streamflow attributable to systematic landuse changes, changes in groundwater gains or losses, climate cycles and changes, statistical vagaries, and other influencing factors. Annual mean streamflow data are especially diagnostic because these statistics can be used to compute mean annual streamflow over long periods of time and represent the expectation of the annual volume of water measured at a streamgage. The 38 streamgages have at least 49 and as many as 97 cumulative years of annual mean streamflow data; the average period of record is 68 years. The minimum contributing drainage area (CDA) is about 43 square miles $\left(\mathrm{mi}^{2}\right)$, the mean CDA is about $788 \mathrm{mi}^{2}$, and the maximum CDA is about $4,190 \mathrm{mi}^{2}$. The streamgages are scattered around the central and eastern parts of Texas.

The Kendall's tau statistical test was used to detect monotonic trends in annual mean streamflow over time. Three stations have statistically significant trends. The monotonic trend analysis detected 2 statistically significant upward trends ( 0.01 one-tail significance), 1 statistically significant downward trend ( 0.01 one-tail significance level), and 35 instances of no statistically significant trend ( 0.02 twotailed significance level). These results are not surprising given that the streamgages were screened to only include those where the streamflow was thought to be natural and unregulated for the entire period of record at each station.

For the three stations where trends in streamflow were detected, the Theil slope estimate of a regression slope of annual mean streamflow with time was computed in units of cubic feet per second $\left(\mathrm{ft}^{3} / \mathrm{s}\right)$. Two increasing Theil slopes were measured $\left(+0.40\right.$ and $+2.72 \mathrm{ft}^{3} / \mathrm{s}$ per year, respectively), and one decreasing Theil slope $\left(-0.24 \mathrm{ft}^{3} / \mathrm{s}\right.$ per year) was measured.

Selected summary statistics (L-moments) and sampling variances for the 35 streamgages lacking statistically significant trends were computed. These statistics of annual mean streamflow for each streamgage represent a collection of different numerical values that together describe the location, scale, and various metrics of shape of the observed data. An example application of selected summary statistics (regional L-moments) to estimate the magnitude and frequency of annual mean streamflow is provided. In this example, the regional L-moments of annual mean streamflow in Texas are used to quantify the scale and shape of a dimensionless regional probability distribution. The term "regional" is intended to encompass a conceptual spatial scale that is congruent with the distribution of the 35 streamgages with natural and unregulated streamflow and lacking statistically significant trends. The 4-parameter asymmetric exponential power (AEP) distribution was chosen from more than 20 possible distribution forms. The example application uses a single regional frequency curve for illustration purposes. A technique was derived that hydrologists and engineers might find useful for evaluating annual mean streamflow in Texas for unregulated watersheds, and the steps for using the algorithm with the data from a given streamgage are described. More refined dimensionless regional frequency curves that account for spatial variation in rainfall (variation in mean annual precipitation for instance), topography, geology, and other potential factors could be developed by following the process outlined in the example application.

\section{References}

Asquith, W.H., 2001, Effects of regulation on L-moments of annual peak streamflow in Texas: U.S. Geological Survey Water-Resources Investigations Report 01-4243, 66 p. (Also available at http://pubs.usgs.gov/wri/wri014243/.)

Asquith, W.H., 2011, Distributional analysis with L-moment statistics using the R environment for statistical computing: First edition, CreateSpace Independent Publishing Platform, ISBN 978-1463508418.

Asquith, W.H., 2013, Imomco-L-moments, censored L-moments, trimmed L-moments, L-comoments, and many distributions: R package version 1.7.5, dated March 30, 2013. (Also available at http://www.cran.r-project.org/ package $=$ lmomco.) 
Asquith, W.H., 2014, Parameter estimation for the 4-parameter Asymmetric Exponential Power distribution by the method of L-moments using R: Scheduled for release in Computational Statistics \& Data Analysis, v. 71, p. 955-970.

Asquith, W.H., and Heitmuller, F.T., 2008, Summary of annual mean and annual harmonic mean statistics of daily mean streamflow for 620 U.S. Geological Survey streamgages in Texas through water year 2007: U.S. Geological Survey Data Series 372, 1259 p. (Also available at http://pubs.usgs. gov/ds/372/.)

Asquith, W.H., and Roussel, M.C., 2004, Atlas of depthduration frequency of precipitation annual maxima for Texas: U.S. Geological Survey Scientific Investigations Report 2004-5041, 106 p. (Also available at http://pubs. usgs.gov/sir/2004/5041/.)

Asquith, W.H., and Roussel, M.C., 2009, Regression equations for estimation of annual peak-streamflow frequency for undeveloped watersheds in Texas using an L-momentbased, PRESS-minimized, residual-adjusted approach: U.S. Geological Survey Scientific Investigations Report 2009-5087, 48 p. (Also available at http://pubs.usgs.gov/ $\operatorname{sir} / 2009 / 5087 /$.)

Asquith, W.H., Roussel, M.C., Cleveland, T.G., Fang, Xing, and Thompson, D.B., 2006, Statistical characteristics of storm interevent time, depth, and duration for eastern New Mexico, Oklahoma, and Texas: U.S. Geological Survey Professional Paper 1725, 299 p. (Also available at http://pubs.usgs.gov/pp/pp1725/.)

Asquith, W.H., and Slade, R.M., 1997, Regional equations for estimation of peak-streamflow frequency for natural basins in Texas: U.S. Geological Survey Water-Resources Investigations Report 96-4307, 68 p. (Also available at http://pubs.usgs.gov/wri/wri964307.)

Asquith, W.H., Vrabel, Joseph, and Roussel, M.C., 2007a, Summary of percentages of zero daily mean streamflow for 712 U.S. Geological Survey streamgages in Texas through 2003: U.S. Geological Survey Data Series 247, 721 p. (Also available at http://pubs.usgs.gov/ds/2007/247/.)

Asquith, W.H., Vrabel, Joseph, and Roussel, M.C., 2007b, Summary of annual mean, maximum, minimum, and L-scale statistics of daily mean streamflow for 712 U.S. Geological Survey streamgages in Texas through 2003: U.S. Geological Survey Data Series 248, 721 p. (Also available at http://pubs.usgs.gov/ds/2007/248/.)

Barbie, D.L., and Wehmeyer, L.L., 2012, Trends in selected streamflow statistics at 19 long-term streamflow-gaging stations indicative of outflows from Texas to Arkansas, Louisiana, Galveston Bay, and the Gulf of Mexico, 19222009: U.S. Geological Survey Scientific Investigations Report 2012-5182, 20 p. (Revised September 2012) (Also available at http://pubs.usgs.gov/sir/2012/5182/.)
Barbie, D.L., Wehmeyer, L.L., and May, J.E., 2012, Analysis of trends in selected streamflow statistics for the Concho River Basin, Texas, 1916-2009: U.S. Geological Survey Scientific Investigations Report 2012-5193, 15 p. (Also available at http://pubs.usgs.gov/sir/2012/5193/.)

Dowell, C.L., 1964, Dams and reservoirs in Texas-Historical and descriptive information: Texas Water Commission Bulletin 6408, accessed June 8, 2013, at http://www.twdb. texas.gov/publications/reports/bulletins/doc/B6408.pdf.

Helsel, D.R., and Hirsch, R.M., 2002, Statistical methods in water resources: U.S. Geological Survey Techniques of Water-Resources Investigations book 4, chap. A3. (Also available at http://pubs.usgs.gov/twri/twri4a3.)

Hollander, Myles, and Wolfe, D.A., 1973, Nonparametric statistical methods: New York, John Wiley.

Hosking, J.R.M., 1990, L-moments-Analysis and estimation of distributions using linear combination of order statistics: Journal Royal Statistical Society B, v. 52, no. 1, p. 105-124.

Hosking, J.R.M., and Wallis, J.R., 1997, Regional frequency analysis-An approach based on L-moments: Cambridge, Cambridge University Press.

Karian, Z.M., and Dudewicz, E.J., 2010, Handbook of fitting statistical distributions with R: Boca Raton, CRC Press.

Kenny, J.F., Barber, N.L., Hutson, S.S., Linsey, K.S., Lovelace, J.K., and Maupin, M.A., 2009, Estimated use of water in the United States in 2005: U.S. Geological Survey Circular 1344, 52 p. (Also available at http://pubs.usgs.gov/ circ/1344/.)

Lanning-Rush, Jennifer, 2000, Regional equations for estimating mean annual and mean seasonal runoff for natural basins in Texas, base period 1961-90: U.S. Geological Survey Water-Resources Investigations Report 00-4064, 27 p. (Also available at http://pubs.usgs.gov/ wri/2000/4064/.)

Nuñez, J.H., Verbist, Koen, Wallis, J.R., Schaefer, M.G., Morales, Luis, and Cornelis, W.M., 2011, Regional frequency analysis for mapping drought events in northcentral Chile: Journal of Hydrology, v. 405, p. 352-366.

R Development Core Team, 2012, R-A language and environment for statistical computing: Vienna, Austria, R Foundation for Statistical Computing. ISBN 3-90005107-0. (Also available at http://www.R-project.org/.)

Rizzo, M.L., 2008, Statistical computing with R: Boca Raton, Chapman and Hall/CRC.

Slade, R.M., Jr., Howard, Teresa, and Anaya, Roberto, 2001, Evaluation of the streamflow-gaging network of Texas and a proposed core network: U.S. Geological Survey WaterResources Investigations Report 01-4155, 40 p., 1 plate. (Also available at http://pubs.usgs.gov/wri/wri014155/.) 
Stedinger, J.R., Vogel, R.M., and Foufoula-Georgiou, Efi, 1993, Frequency analysis of extreme events, chapter 18, in Maidment, D.A., ed., Handbook of hydrology: New York, McGraw-Hill, p. 18.1-18.66.

Texas Commission on Environmental Quality, 2013, Water availability and water rights permits: accessed on March 13, 2013, at http://www.tceq.texas.gov/permitting/water_ supply/water_rights.

Texas State Historical Association, 2013, The handbook of Texas online: Texas State Historical Association, accessed March 8, 2013, at http://www.tshaonline.org/search/node/ Reservoirs.

Ugarte, M.D., Militino, A.F., and Arnholt, A.T., 2008, Probability and statistics with R: Boca Raton, Chapman and Hall/CRC.

U.S. Geological Survey, 2013, National Water Information System: accessed September 25, 2013, at http://waterdata. usgs.gov/tx/nwis/.
Verzani, John, 2005, Using R for introductory statistics: Boca Raton, Chapman and Hall/CRC.

Viglione, Alberto, 2010, Confidence intervals for the coefficient of L-variation in hydrological applications:

Hydrology and Earth System Sciences, v. 14, p. 2229-2242.

Vogel, R.M., and Fennessey, N.M., 1993, L moment diagrams should replace product moment diagrams: Water Resources Research, v. 29, no. 6, p. 1745-1752.

Wang, Dongliang, and Hutson, A.D., 2013, Joint confidence region estimation of L-moments with an extension to right censored data: Journal of Applied Statistics, v. 40, no. 2, p. 368-379.

Winters, K.E., 2013, A historical perspective on precipitation, drought severity, and streamflow in Texas during 1951-56 and 2011: U.S. Geological Survey Scientific Investigations Report 2013-5113, 34 p. (Also available at http://pubs.usgs. gov/sir/2013/5113/.) 
I SBN 978- 1- 4113-3760- 2 